\title{
Old and new specimens of a poorly known glyptodont from the Miocene of Patagonia and their biochronological implications
}

\author{
Laureano Raúl González Ruiz, Agustina Reato, Martín Cano, and Oscar Martínez \\ Acta Palaeontologica Polonica 62 (1), 2017: 181-194 doi:http://dx.doi.org/10.4202/app.00280.2016
}

The Palaehoplophorini is a tribe of glyptodonts represented by fragmentary specimens for which the oldest records occur in the Pedregoso and Río Mayo formations (middle-late Miocene) in Patagonia (Argentina). The mammal fossils from those formations were the basis for the recognition of the Mayoan fauna, placed between the Friasian sensu stricto/Colloncuran-Laventan and the Chasicoan faunas. The only identified glyptodont from Río Mayo Formation is Palaehoplophorus meridionalis represented only by its type material (i.e., caudal tube) and the precise provenance is unknown. We describe a new specimen of Palaehoplophorus meridionalis collected in the Río Mayo Formation represented by associated osteoderms of the dorsal carapace and postcranial elements, plus part of the type and assigned specimens that remain unpublished from the old collection. This is the first description of osteoderms from the dorsal carapace of this species and postcranial elements (the first for a Palaehoplophorini), and the first glyptodont with precise provenance from Río Mayo Formation. As result of improving the description and emending the diagnosis, we agree with previous authors about the basal position of Palaehoplophorus meridionalis within the tribe. Finally, we review the Glyptodontidae association of the Mayoan fauna, which are exclusively represented by Palaehoplophorini (Palaehoplophorus meridionalis and Palaehoplophoroides rothi) and Glyptodontidae indet. This association supports a greater affinity of this fauna with the younger Chasicoan than with the older Friasian sensu stricto/Colloncuran-Laventan faunas.

Key words: Mammalia, Glyptodontidae, Palaehoplophorus, Miocene, Río Mayo Formation,Patagonia.

Laureano Raúl González Ruiz [gonzalezlaureano@yahoo.com.ar], Agustina Reato [agustinareato@yahoo.com.ar], and Oscar Martínez [oam1958@gmail.com ], Centro de Investigación Esquel de Montaña y Estepa Patagónica (CIEMEP) (CONICET-UNPSJB), Roca 780, 9200, Esquel, Chubut, Argentina. Martín Cano [martinbahia@hotmail.com], Universidad Nacional del Sur, Departamento de Geología (CONICET), San Juan 670, Bahía Blanca, Buenos Aires, Argentina. 
This is an open-access article distributed under the terms of the Creative Commons

Attribution License (for details please see creativecommons.org), which permits unrestricted use, distribution, and reproduction in any medium, provided the original author and source are credited.

Forill text $(600.2 \mathrm{kB})$ 